\title{
Preparation of Spherical Zn-Substituted Tricalcium Phosphate Powder by Ultrasonic Spray-Pyrolysis Technique and Its Characterization
}

\author{
Hiroki Nishikawa, ${ }^{1,2}$ Michiyo Honda, ${ }^{3}$ Tomohiro Yokota, ${ }^{1}$ \\ Yusuke Shimizu, ${ }^{1}$ and Mamoru Aizawa ${ }^{1}$ \\ ${ }^{1}$ Department of Applied Chemistry, School of Science and Technology, Meiji University, 1-1-1 Higashimita, Tama-ku, \\ Kawasaki, Kanagawa 214-8571, Japan \\ ${ }^{2}$ Department of Chemistry, Faculty of Mathematics and Natural Sciences, Heinrich-Heine-University Düsseldorf, \\ Universitätsstraße 1, 40225 Düsseldorf, Germany \\ ${ }^{3}$ Organization for the Strategic Coordination of Research and Intellectual Property, Meiji University, 1-1-1 Higashimita, \\ Tama-ku, Kawasaki, Kanagawa 214-8571, Japan
}

Correspondence should be addressed to Michiyo Honda; michiyoh@meiji.ac.jp

Received 21 November 2015; Accepted 4 February 2016

Academic Editor: Chuan Zhang

Copyright ( 2016 Hiroki Nishikawa et al. This is an open access article distributed under the Creative Commons Attribution License, which permits unrestricted use, distribution, and reproduction in any medium, provided the original work is properly cited.

\begin{abstract}
Zinc, an essential trace element, has a stimulatory effect on bone formation. To enhance the osteoconduction of implant materials such as hydroxyapatite and tricalcium phosphate (TCP), zinc was incorporated into them. In this study, we have synthesized spherical zinc-substituted TCP (Zn-TCP) powders using ultrasonic spray-pyrolysis technique, fabricated Zn-TCP ceramics, and characterized their powder properties. Four kinds of Zn-TCPs with various amounts of zinc content were prepared, to examine the influence of zinc addition to the crystal structure of TCP and to compare the different Zn-TCPs with each other. Zn-TCP ceramics were fabricated from the resulting powders under different sintering temperatures. Zn-TCP samples were analyzed and led to the following results: the resulting powders were composed of $\alpha$ - and $\beta$-TCP phases, whereas the fabricated ceramics mainly consisted of $\beta$-TCP phase. The determination of zinc content in the resulting powders and fabricated ceramics showed a maximum content of $\sim 12 \mathrm{~mol} \%$. The resulting powders consisted of spherical particles with diameters $<2 \mu \mathrm{m}$. The lattice constants of ceramics did not show a significant change of the $a$-axis, $b$-axis, and $c$-axis. The bulk density of $\mathrm{Zn}$-TCPs showed their maximum at $1100^{\circ} \mathrm{C}$, while the bulk density of $\mathrm{Zn}-\mathrm{TCP}(0)$ was greatest at $1000^{\circ} \mathrm{C}$.
\end{abstract}

\section{Introduction}

Both hydroxyapatite (HAp; $\left.\mathrm{Ca}_{10}\left(\mathrm{PO}_{4}\right)_{6}(\mathrm{OH})_{2}\right)$ and tricalcium phosphate (TCP; $\left.\mathrm{Ca}_{3}\left(\mathrm{PO}_{4}\right)_{2}\right)$ are known for their properties regarding the biocompatibility and osteoconductivity. Moreover, because of their composition, which is close to human hard tissues such as living bones and teeth, they can be used as bone graft substitute materials in medical treatment approaches [1].

The HAp is thermodynamically the stable phase at physiological $\mathrm{pH}$ and forms a direct chemical bond with hard tissues [2]. On the other hand, the TCP is typically more soluble and less crystalline than HAp, and its cell-mediated bioresorption is faster. Therefore, TCP permits a gradual replacement of the implant by the newly formed bone [3].

For the synthesis of such a HAp or TCP powder, one can basically distinguish between two types of preparation methods [4]: the first method is a dry process or a solidstate reaction between calcium and phosphate salts under steam atmosphere. The second one is a wet process or a liquid-phase reaction between calcium and phosphate ions under alkaline conditions. Both of the preparation methods have their advantages and disadvantages. For the preparation of stoichiometric apatite powders, the dry process seems to 
TABLE 1: Nominal composition of the Zn-TCP starting solutions.

\begin{tabular}{|c|c|c|c|c|c|c|}
\hline Sample & $\mathrm{Ca}\left(\mathrm{NO}_{3}\right)_{2} / \mathrm{mol} \cdot \mathrm{dm}^{-3}$ & $\left(\mathrm{NH}_{4}\right)_{2} \mathrm{HPO}_{4} / \mathrm{mol} \cdot \mathrm{dm}^{-3}$ & $\mathrm{HNO}_{3} / \mathrm{mol} \cdot \mathrm{dm}^{-3}$ & $\mathrm{Zn}\left(\mathrm{NO}_{3}\right)_{2} \cdot 6 \mathrm{H}_{2} \mathrm{O} / \mathrm{mol} \cdot \mathrm{dm}^{-3}$ & $\mathrm{Zn} / \mathrm{mol} \%$ & $\mathrm{Ca} / \mathrm{P}$ \\
\hline $\mathrm{Zn}-\mathrm{TCP}(0)$ & 0.60 & 0.40 & 0.40 & - & - & \multirow{4}{*}{1.50} \\
\hline $\mathrm{Zn}-\mathrm{TCP}(5)$ & 0.60 & 0.40 & 0.40 & 0.01 & 5 & \\
\hline $\mathrm{Zn}-\mathrm{TCP}(10)$ & 0.60 & 0.40 & 0.40 & 0.02 & 10 & \\
\hline $\mathrm{Zn}-\mathrm{TCP}(15)$ & 0.60 & 0.40 & 0.40 & 0.03 & 15 & \\
\hline
\end{tabular}

be an effective method. However, due to the presence of hard agglomerates with undetermined shapes, the resulting powder shows poor sinterability. On the other hand, the HAp powder obtained by a wet process tends to form a nonstoichiometric apatite powder or a calcium-deficient HAp powder, when the conditions for HAp preparations are not strictly controlled, regardless of the excellent sinterability of the resulting powders.

In this study, the ultrasonic spray-pyrolysis (USSP) technique was used for the synthesis of TCP powders. The USSP technique is one of the powder preparation methods via the liquid phases $[5,6]$. The advantage of this method is that one can prepare stoichiometric and homogeneous compounds instantaneously by spraying the solutions with the desired amounts of cations into the hot zone of an electric furnace. Especially for the preparation of HAp-like materials containing the hydroxyl group in the crystalline structure, this method is effective and the powders can be prepared directly in a steam atmosphere during spray-pyrolysis [7-9].

In previous works, the preparation of various calcium phosphates, for example, HAp [7, 9, 10], TCP [11, 12], calcium diphosphate [12], calcium metaphosphate [13], trace elements substituted calcium phosphates such as strontiumsubstituted HAp [14], silicon-substituted HAp [15], and silvercontaining HAp [16] by the USSP technique was reported. The effects of the kinds of the starting materials on properties of HAp powders prepared by the USSP technique were also examined [10].

These HAp and TCP possess osteoconductive properties but have no osteoinductive capacity. One solution to develop bone substitutes with osteogenic properties would be to adjust the chemical composition to more closely approximate that of bone mineral [17].

Zinc, an essential trace element, is important for growth and stimulation of bone formation. Additionally, zinc could inhibit the effect on osteoclastic bone resorption [18]. Therefore, the release of zinc incorporated into an implant material could enhance the bone formation around the implant site. However, zinc must be released slowly from the implant because zinc at an elevated level induces adverse reactions [19]. For the slow release of zinc, we have chosen $\beta$-TCP, which could be the adequate zinc carriers.

In the present study, we prepared an essential trace element containing calcium phosphate using the USSP technique, namely, zinc-substituted TCP. The aim of this study was to investigate the effect of zinc incorporation into the TCP structure. Therefore, zinc-containing TCP powders (hereafter, $\mathrm{Zn}$-TCP) and the respective ceramics with various zinc content of $0,5,10$, or $15 \mathrm{~mol} \%$ were prepared and subsequently characterized using different analysis methods.
Future studies on Zn-TCP will involve in vitro studies to evaluate its biocompatibility and its ability to induce bone formation and inhibit osteoclast bone resorption.

\section{Materials and Methods}

2.1. Preparation of Zn-TCP Powders Using USSP Technique and Ceramics Fabrication. As previously reported [14-16], the USSP apparatus was composed of an atomizer, a heating zone (Mullite tube: ID of $2.5 \mathrm{~cm}$ and a height of $1 \mathrm{~m}$; electric furnace: ID of $3 \mathrm{~cm}$ and a height of $60 \mathrm{~cm}$ ), a powder collecting zone (test-tube filter), and a controller. The heating section was divided into two electric furnaces: a lower furnace for the evaporation of the solvent from the droplets (temperature: $300^{\circ} \mathrm{C}$ ) and an upper furnace for the pyrolysis (temperature: $1000^{\circ} \mathrm{C}$ ). The aspirator was used to let the droplets be gathered together (suction rate: $2 \mathrm{dm}^{3} \cdot \mathrm{min}^{-1}$ ).

As listed in Table 1, four kinds of starting solutions with a ratio of calcium and phosphorus $(\mathrm{Ca} / \mathrm{P})=1.5$ were prepared by mixing the following compounds: $\mathrm{Ca}\left(\mathrm{NO}_{3}\right)_{2}$, $\left(\mathrm{NH}_{4}\right)_{2} \mathrm{HPO}_{4}, \mathrm{HNO}_{3}$, and $\mathrm{Zn}\left(\mathrm{NO}_{3}\right)_{2} \cdot 6 \mathrm{H}_{2} \mathrm{O}$.

The resulting powders ( $\sim 5 \mathrm{~g})$ were compressed at $100 \mathrm{MPa}$ to prepare disc shaped green compacts (diameter: $\sim 15 \mathrm{~mm}$; thickness: $\sim 1.5 \mathrm{~mm}$ ). Those green compacts were sintered at $1000^{\circ} \mathrm{C}, 1100^{\circ} \mathrm{C}, 1200^{\circ} \mathrm{C}$, and $1300^{\circ} \mathrm{C}$ for $5 \mathrm{~h}$ (heating rate: $\left.10^{\circ} \mathrm{C} \cdot \mathrm{min}^{-1}\right)$ to fabricate the respective ceramics.

\subsection{Characterization of the Resulting Powders and Fabricated} Ceramics. Both the crystalline phases of the powders (Miniflex, Rigaku, Japan) and the ceramics (Ultima IV, Rigaku, Japan) were identified by X-ray diffraction (XRD) using $\mathrm{CuK} \alpha$ radiation at a range of $2 \theta=10-50^{\circ}$, generated at $30 \mathrm{kV}$ and $15 \mathrm{~mA}$ with a step size of $2^{\circ} / \mathrm{min}$. The crystalline phases were identified on the basis of the JCPDS reference data. The lattice constants in the ceramic structures were calculated by refinement of the collected XRD data. Therefore, the refinement software PDXL was used according to the manufacturer's instructions (Rigaku).

The morphology of the powder particles and ceramics was observed by scanning electron microscope (SEM; JSM6390LA, JEOL, Japan) at a magnification range of $\times 5,000$ and $\times 10,000$ with an accelerating voltage of $15 \mathrm{kV}$.

The amount of zinc concentration in each powder and ceramic sample was measured by inductive coupled plasma atomic emission spectroscopy (ICP-AES; SPS7800, SII Nanotechnology, Japan).

Furthermore, Fourier transform infrared (FT-IR; IR Prestige-21, Shimadzu, Japan) spectra of the powders were 


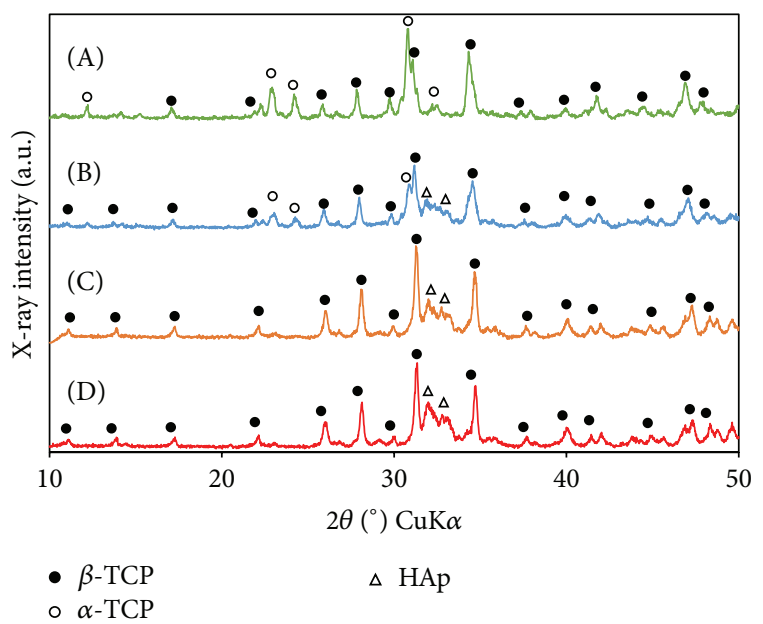

FIGURE 1: The XRD patterns of the resulting Zn-TCP powders derived from various starting solutions: (A) Zn-TCP(0), (B) ZnTCP(5), (C) Zn-TCP(10), and (D) Zn-TCP(15).

recorded in a range of $400-4000 \mathrm{~cm}^{-1}$ by potassium bromide $(\mathrm{KBr})$ pellet method.

The median particle size of the powder samples was determined by particle size distribution analysis (PSD; LA300 , Horiba, Japan). Diluting $\sim 0.3 \mathrm{~g}$ of each powder in distilled water was measured under an ultrasonic working condition.

The bulk density of the fabricated disc shaped ceramics was calculated using the following formula considering diameter, height, and weight of ceramic:

$$
\text { Bulk density }=\frac{\text { weight of ceramic specimens }[\mathrm{g}]}{\text { volume of ceramic specimens }\left[\mathrm{cm}^{3}\right]}
$$

\section{Results and Discussion}

3.1. Characterization of Zn-TCP Powders. The XRD patterns of the resulting Zn-TCP powders are shown in Figure 1. As one can see, the crystalline phases were mainly composed of $\alpha$ - and $\beta$-TCP phases. However, a little HAp phase was detected in Zn-TCP $(5,10,15)$ powders. It is apparent that the peak intensity of $\beta$-TCP phase became stronger with increasing zinc concentration at a range of $2 \theta=31-32^{\circ}$. Indeed, the ratio of $\beta$-TCP phase increased with the increment of $\mathrm{Zn}$ concentration. Another aspect was the shifting of the peaks towards higher angles in this range, which is related to the zinc content in the resulting powders. Apparently, the shifting would be related to the change in the size of the unit cell and thus the decrease of the lattice constants with increasing zinc concentration and was also confirmed in other published works [20].

FT-IR spectra of the Zn-TCP powders were recorded in a range of $400-4000 \mathrm{~cm}^{-1}$ (Figure 2). The results show the characteristic absorption bands of TCP. The absorptions assigned to the $\mathrm{PO}_{4}{ }^{3-}$ group [21] were detected at 1120 1020 and $600-560 \mathrm{~cm}^{-1}$. The $\mathrm{OH}^{-}$group was detected at $\sim 3420 \mathrm{~cm}^{-1}$ [21]. Either any absorptions assigned to $\mathrm{NO}_{3}{ }^{-}$

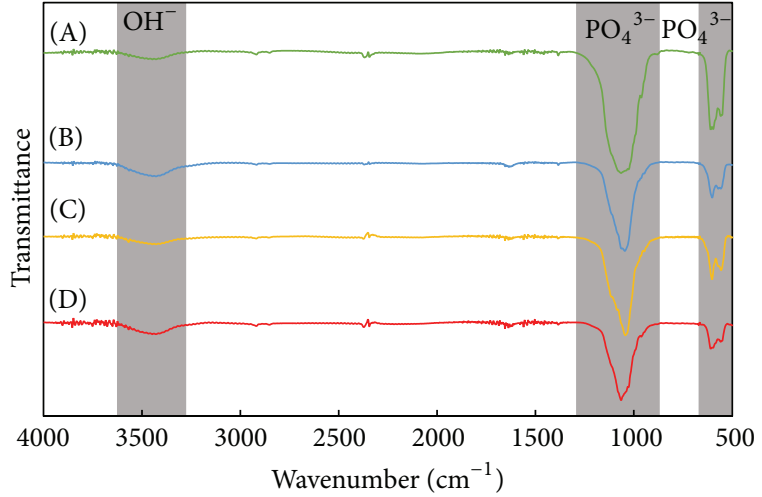

FIgURE 2: The FT-IR spectra of the Zn-TCP powders in a range of $400-4000 \mathrm{~cm}^{-1}$ : (A) Zn-TCP(0), (B) Zn-TCP(5), (C) Zn-TCP(10), and (D) $\mathrm{Zn}-\mathrm{TCP}(15)$.

group or absorptions assigned to the carbonate ion were detected as reported by Monma and Takahashi. Thus, these FT-IR spectra imply an easy preparation of carbonate-free TCP powder by the USSP technique.

The concentrations of $\mathrm{Ca}, \mathrm{P}$, and $\mathrm{Zn}$ in the $\mathrm{Zn}$-TCP powder samples including the $\mathrm{Ca} / \mathrm{P}$ and $(\mathrm{Ca}+\mathrm{Zn}) / \mathrm{P}$ ratio were measured by ICP-AES (Table 2). The $\mathrm{Zn}$ fraction for each composition was represented as $([\mathrm{Zn}] /[\mathrm{Ca}+\mathrm{Zn}])$ $\times 100(\mathrm{~mol} \%)$. The comparison between the achieved and expected zinc concentration shows a good approximation under $10 \mathrm{~mol} \%$ of zinc. It may be connected with the fact that the maximum zinc concentration in $\mathrm{Zn}-\mathrm{TCP}$ is $\sim 12 \mathrm{~mol} \%$ [19]. This result could be interpreted as a limitation of zinc incorporation capacity in $\mathrm{Zn}$-TCP.

The morphology of the Zn-TCP powder particles was observed by SEM (Figure 3). The SEM micrographs show that all samples consisted of spherical shaped particles with a diameter smaller than $5 \mu \mathrm{m}$. The spherical shape of the powder particles could be explained via the following process $[22,23]$ : (i) removal of the solvent from the droplet surface, (ii) formation of microcrystalline calcium phosphate, and (iii) crystal growth of calcium phosphates. The resulting spherical particle diameters depend on the droplet sizes of the starting solutions, carrier gas, rate of gas flow, or temperature of pyrolysis. Although the droplet size might be changeable with zinc concentration of the starting solutions, no apparent changes were seen in the spherical particle diameters. Moreover, the median particle size of the $\mathrm{Zn}$-TCP powder samples was determined (Figure 4). The median size of each powder was $1.65 \pm 0.12 \mu \mathrm{m}$ for $\mathrm{Zn}-\mathrm{TCP}(0), 2.07 \pm$ $0.05 \mu \mathrm{m}$ for $\mathrm{Zn}-\mathrm{TCP}(5), 1.92 \pm 0.02 \mu \mathrm{m}$ for $\mathrm{Zn}-\mathrm{TCP}(10)$, and $1.91 \pm 0.04 \mu \mathrm{m}$ for $\mathrm{Zn}-\mathrm{TCP}(15)$, respectively. There were no significant differences among $\mathrm{Zn}-\mathrm{TCP}(5,10$, or 15$)$ powders regardless of $\mathrm{Zn}$ concentration in the starting solution.

3.2. Fabrication of Zn-TCP Ceramics and Their Properties. Figures 5(a) and 5(b) show the typical XRD patterns of the fabricated $\mathrm{Zn}-\mathrm{TCP}(0)$ and $\mathrm{Zn}-\mathrm{TCP}(10)$ ceramics under different sintering temperatures, respectively. Compared to the phase composition of the resulting powders, the crystalline 


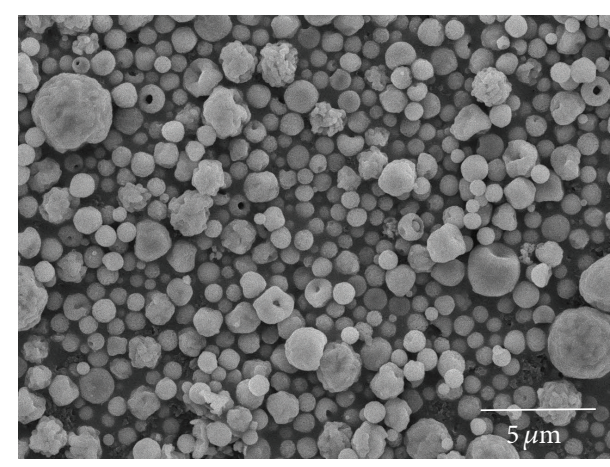

(a)

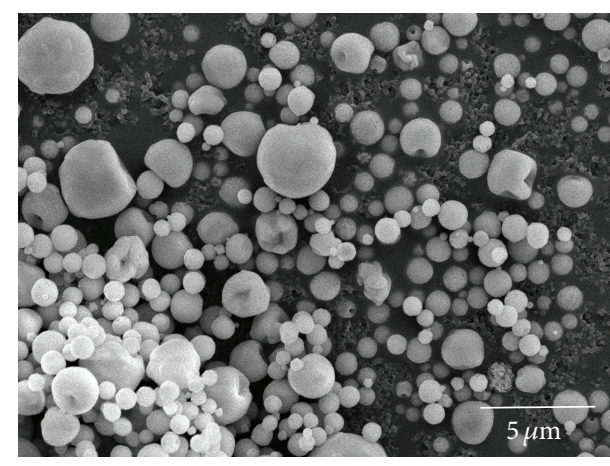

(c)

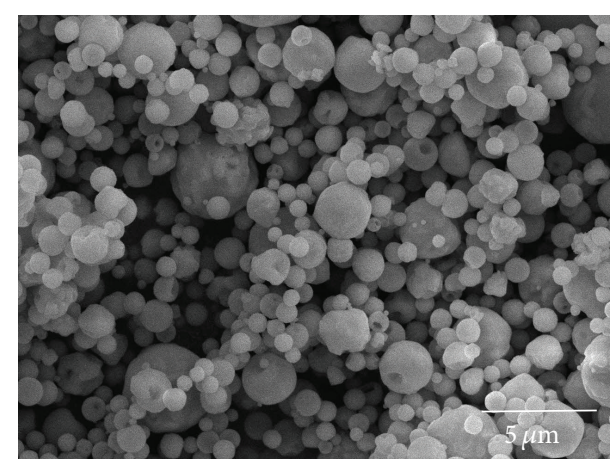

(b)

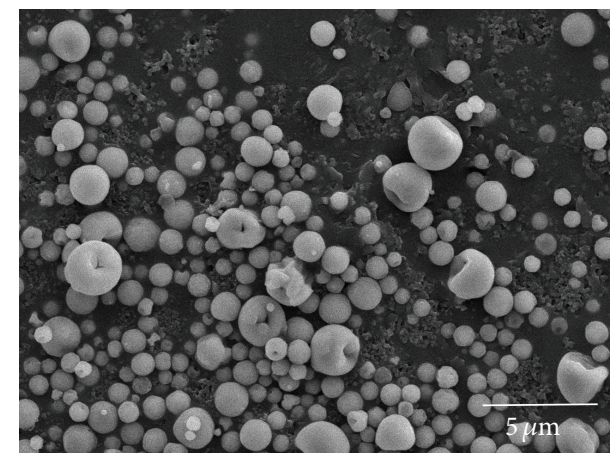

(d)

FIGURE 3: The SEM micrographs of the resulting Zn-TCP powders: (a) Zn-TCP(0), (b) Zn-TCP(5), (c) Zn-TCP(10), and (d) Zn-TCP(15).

TABLe 2: Contents of $\mathrm{Ca}, \mathrm{P}$, and $\mathrm{Zn}$ in the resulting $\mathrm{Zn}-\mathrm{TCP}$ powders including the $\mathrm{Ca} / \mathrm{P}$ and $(\mathrm{Ca}+\mathrm{Zn}) / \mathrm{P}$ ratios.

\begin{tabular}{|c|c|c|c|c|c|c|}
\hline Sample & $\mathrm{Ca} / \mathrm{mol} \%$ & $\mathrm{P} / \mathrm{mol} \%$ & $\mathrm{Zn} / \mathrm{mol} \%$ (expected) & $\mathrm{Zn} / \mathrm{mol} \%$ (achieved) & $\mathrm{Ca} / \mathrm{P}$ & $(\mathrm{Ca}+\mathrm{Zn}) / \mathrm{P}$ \\
\hline $\mathrm{Zn}-\mathrm{TCP}(0)$ & $59.89 \pm 0.18$ & $40.11 \pm 0.18$ & - & - & $1.49 \pm 0.01$ & - \\
\hline $\mathrm{Zn}-\mathrm{TCP}(5)$ & $60.07 \pm 0.33$ & $39.84 \pm 0.33$ & 5 & $4.18 \pm 0.08$ & $1.51 \pm 0.02$ & $1.53 \pm 0.02$ \\
\hline $\mathrm{Zn}-\mathrm{TCP}(10)$ & $59.69 \pm 0.34$ & $40.13 \pm 0.36$ & 10 & $9.21 \pm 1.25$ & $1.49 \pm 0.02$ & $1.53 \pm 0.02$ \\
\hline $\mathrm{Zn}-\mathrm{TCP}(15)$ & $59.58 \pm 0.69$ & $40.16 \pm 0.08$ & 15 & $12.75 \pm 0.41$ & $1.48 \pm 0.01$ & $1.55 \pm 0.00$ \\
\hline
\end{tabular}

phase of the $\mathrm{Zn}$-TCP ceramics was mainly composed of $\beta$ TCP phase at $1000^{\circ} \mathrm{C}$ for $\mathrm{Zn}-\mathrm{TCP}(0)$ and $1100^{\circ} \mathrm{C}$ for $\mathrm{Zn}$ $\mathrm{TCP}(10)$. In addition, $\mathrm{Zn}-\mathrm{TCP}(5)$ and (15) ceramics were also composed of $\beta$-TCP phase at $1100^{\circ} \mathrm{C}$ (data not shown). These results demonstrated that $\beta$-TCP phase in $\mathrm{Zn}$-TCP ceramics could be obtained under $1100^{\circ} \mathrm{C}$. Previous report showed that the dominating occurrence of $\beta$-TCP phase might be related to the fact that the structure of zinc-substituted $\beta$-TCP is more stable than $\alpha$-TCP [24].

The contents of $\mathrm{Ca}, \mathrm{P}$, and $\mathrm{Zn}$ in $\mathrm{Zn}$-TCP ceramics including the $\mathrm{Ca} / \mathrm{P}$ and $(\mathrm{Ca}+\mathrm{Zn}) / \mathrm{P}$ ratio were determined by ICP-AES (Table 3). Compared to the achieved values of the $\mathrm{Zn}$-TCP powders, the concentration of zinc in each ceramic sample was lower. Moreover, the maximum zinc concentration in $\mathrm{Zn}$-TCP ceramic samples also seemed to be $\sim 12 \mathrm{~mol} \%$ as in the powder samples. These data were consistent with previous study [19].

The morphology of the polished surface of the ceramics derived from the powder samples was observed by SEM (Figure 6). Those sintered compacts seemed to be composed of various sized grains. The comparison of $\mathrm{Zn}-\mathrm{TCP}(0)$ and
$\mathrm{Zn}$-TCP $(5,10,15)$ clearly showed the difference of the grain size. The grain size of $\mathrm{Zn}-\mathrm{TCP}(5,10,15)$ was smaller than that of $\mathrm{Zn}-\mathrm{TCP}(0)$. These results indicate that substitution of $\mathrm{Zn}$ into $\beta$-TCP inhibited the grain growth.

The lattice constants in the crushed ceramic specimens were refined on the basis of the JCPDS reference data by least-squares analysis. The calculated lattice constant of $a$, (b)-axis was slightly smaller and that of $c$-axis was close to the reported ones of the $\beta$-TCP structure [25]: $a,(b)$-axis = $1.04352(2) \mathrm{nm}$ and $c$-axis $=3.74029(5) \mathrm{nm}$. It also proves that the fabricated ceramics mainly contained $\beta$-TCP phase. An observation of the lattice constants of TCP shows that $a,(b)$ parameters decreased slightly and $c$ parameter did not change significantly (Table 4). Previous investigation demonstrated that decrease of unit cell volume and lattice parameters of $\beta$-TCP were attributed by $\mathrm{Zn}^{2+}$ substitution for $\mathrm{Ca}^{2+}$ in the calcium sites of the $\beta$-TCP structure [26]. Compared with previous reports, $\mathrm{Zn}$ will be solid-soluted into $\beta$-TCP structure.

The relationship between the sintering temperature and the bulk density of the fabricated Zn-TCP ceramics was 


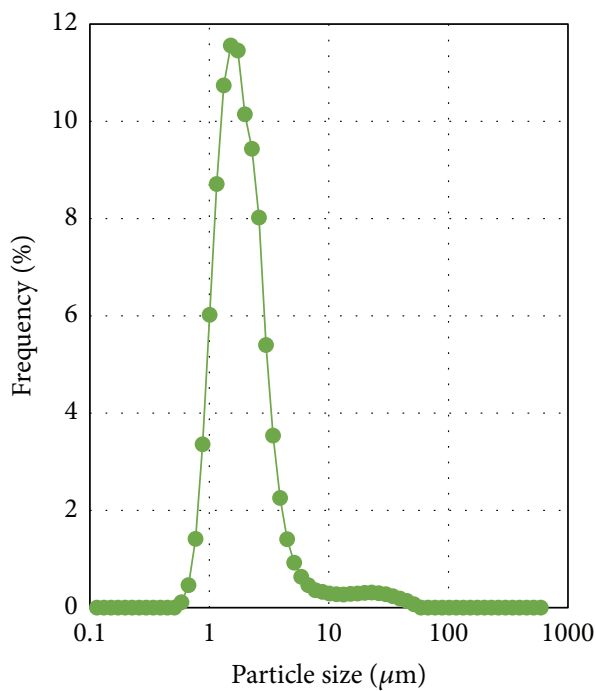

(a)

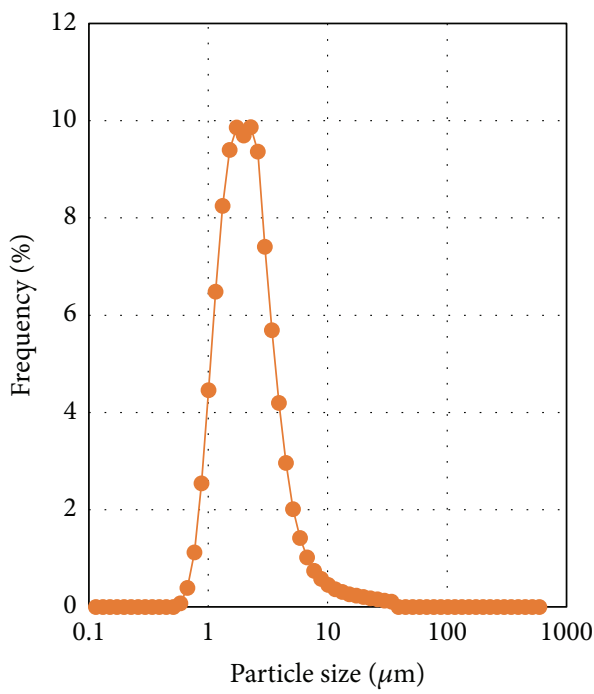

(c)

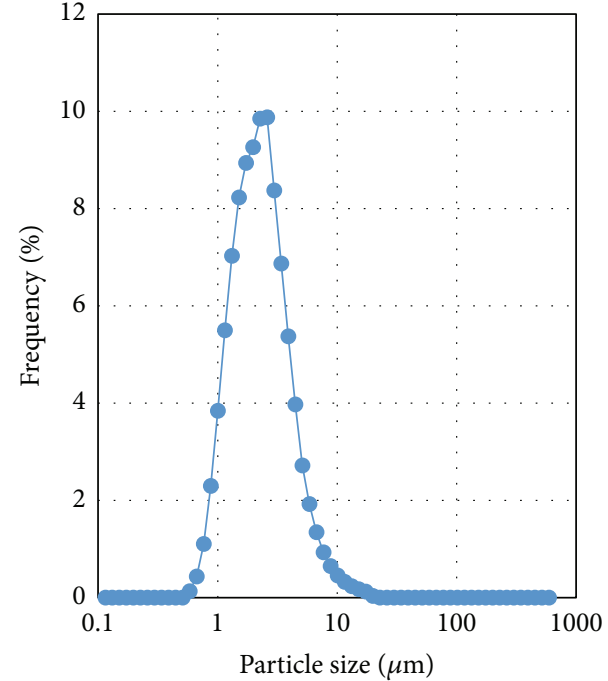

(b)

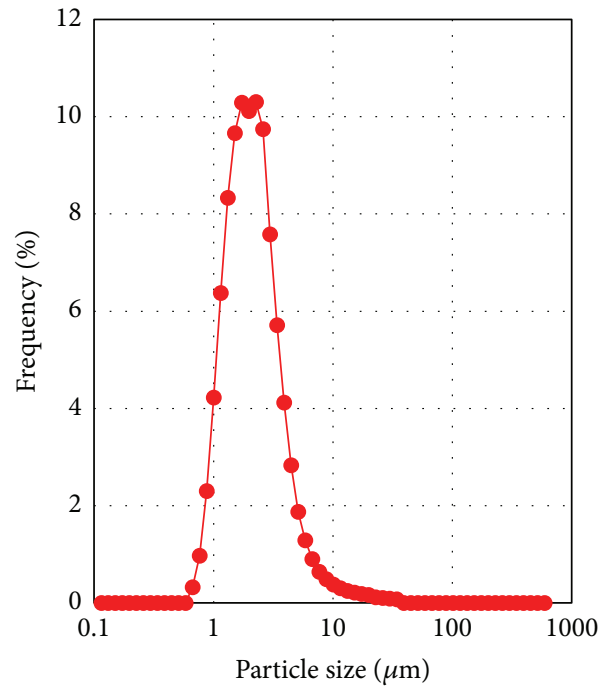

(d)

Figure 4: The particle size distribution of the resulting Zn-TCP powders: (a) Zn-TCP(0), (b) Zn-TCP(5), (c) Zn-TCP(10), and (d) Zn-TCP(15).

TABle 3: Contents of $\mathrm{Ca}, \mathrm{P}$, and $\mathrm{Zn}$ in the fabricated $\mathrm{Zn}-\mathrm{TCP}$ ceramics including the $\mathrm{Ca} / \mathrm{P}$ and $(\mathrm{Ca}+\mathrm{Zn}) / \mathrm{P}$ ratios.

\begin{tabular}{|c|c|c|c|c|c|c|}
\hline Sample & $\mathrm{Ca} / \mathrm{mol} \%$ & $\mathrm{P} / \mathrm{mol} \%$ & $\mathrm{Zn} / \mathrm{mol} \%$ (expected) & $\mathrm{Zn} / \mathrm{mol} \%$ (achieved) & $\mathrm{Ca} / \mathrm{P}$ & $(\mathrm{Ca}+\mathrm{Zn}) / \mathrm{P}$ \\
\hline $\mathrm{Zn}-\mathrm{TCP}(0)$ & $59.98 \pm 0.25$ & $40.01 \pm 0.25$ & - & - & $1.50 \pm 0.02$ & - \\
\hline $\mathrm{Zn}-\mathrm{TCP}(5)$ & $60.40 \pm 0.30$ & $39.52 \pm 0.30$ & 5 & $4.12 \pm 0.08$ & $1.53 \pm 0.02$ & $1.55 \pm 0.02$ \\
\hline $\mathrm{Zn}-\mathrm{TCP}(10)$ & $60.18 \pm 0.02$ & $39.65 \pm 0.01$ & 10 & $8.50 \pm 0.16$ & $1.52 \pm 0.00$ & $1.56 \pm 0.00$ \\
\hline $\mathrm{Zn}-\mathrm{TCP}(15)$ & $59.86 \pm 0.26$ & $39.89 \pm 0.25$ & 15 & $12.30 \pm 0.71$ & $1.50 \pm 0.02$ & $1.56 \pm 0.02$ \\
\hline
\end{tabular}

shown in Figure 7. The bulk density of $\mathrm{Zn}-\mathrm{TCP}(0)$ was the greatest at $1000^{\circ} \mathrm{C}$ and then decreased slightly. Over $1100^{\circ} \mathrm{C}$, the proportion of $\alpha$-TCP in $\mathrm{Zn}$-TCP(0) increased (Figure 5(a)). Transformation of $\beta$-TCP to $\alpha$-TCP phase might affect the decrease of bulk density. On the other hand, the bulk density of $\mathrm{Zn}-\mathrm{TCP}(5,10,15)$ ceramics at $1100^{\circ} \mathrm{C}$ increased compared with that at $1000^{\circ} \mathrm{C}$. These results implied that $\mathrm{Zn}$ - TCP $(5,10,15)$ ceramics were not sintered completely at $1000^{\circ} \mathrm{C}$ (Figure 5(b)). However, at the temperatures $1100-$ $1300^{\circ} \mathrm{C}$, no apparent changes of bulk density among $\mathrm{Zn}$ $\operatorname{TCP}(5,10,15)$ ceramics were seen. In addition, from SEM images, it can be seen that a small amount of micropores 


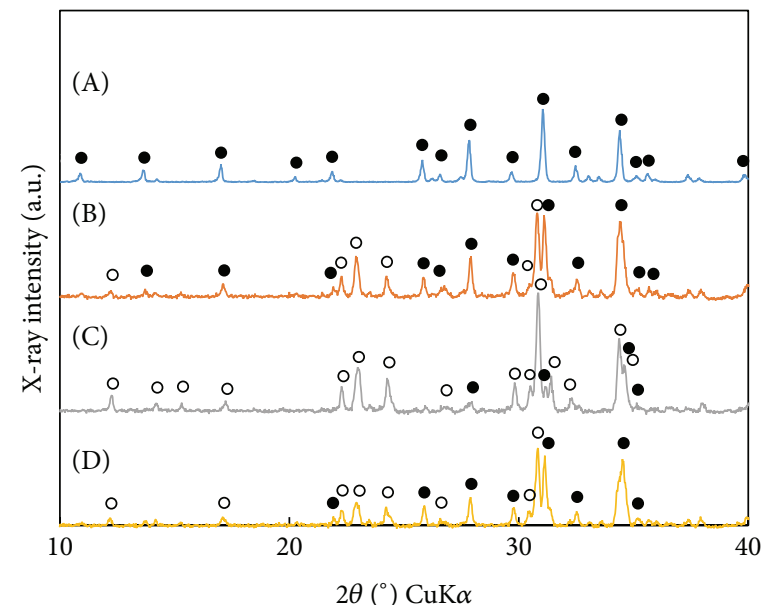

- $\beta$-ТCP

o $\alpha$-ТCP

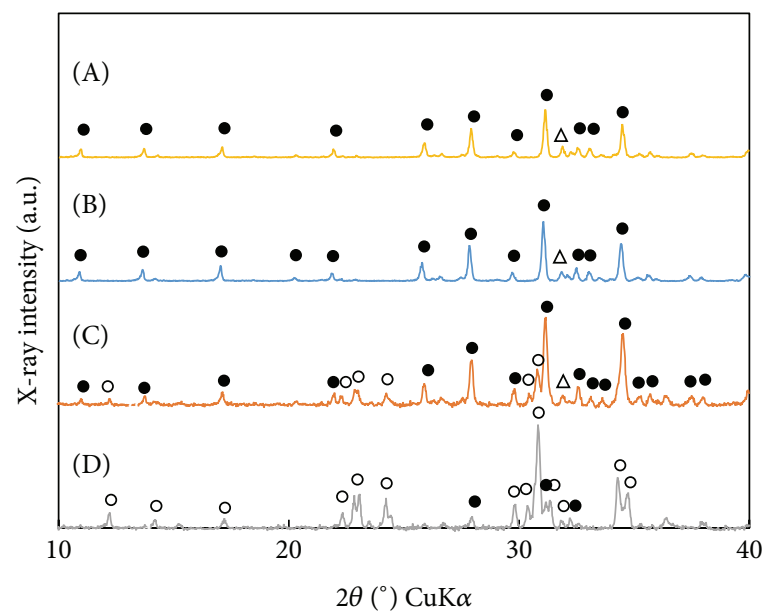

- $\beta$-TCP

- $\alpha$-TCP

(a)

(b)

FIGURE 5: The typical XRD patterns of the fabricated (a) Zn-TCP(0) and (b) Zn-TCP(10) ceramics sintered at (A) $1000^{\circ} \mathrm{C}$, (B) $1100^{\circ} \mathrm{C},(\mathrm{C})$ $1200^{\circ} \mathrm{C}$, and (D) $1300^{\circ} \mathrm{C}$.

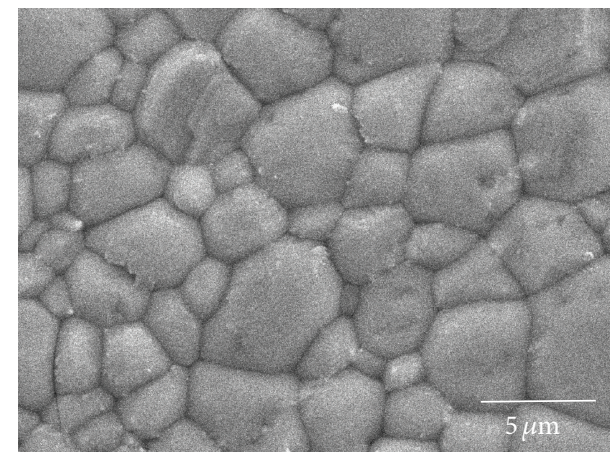

(a)

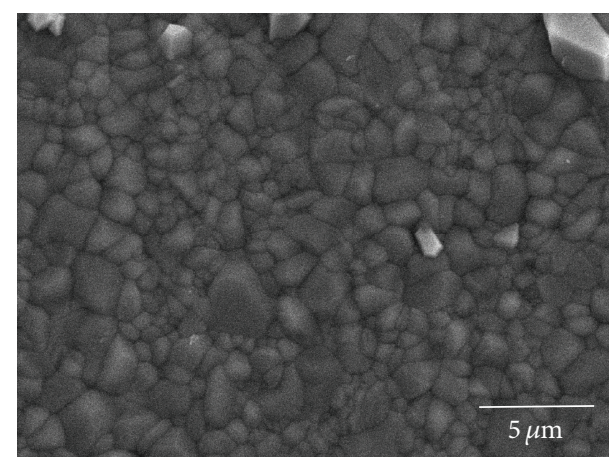

(c)

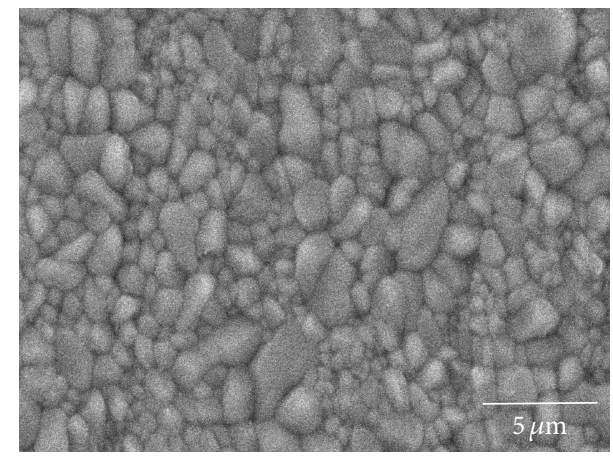

(b)

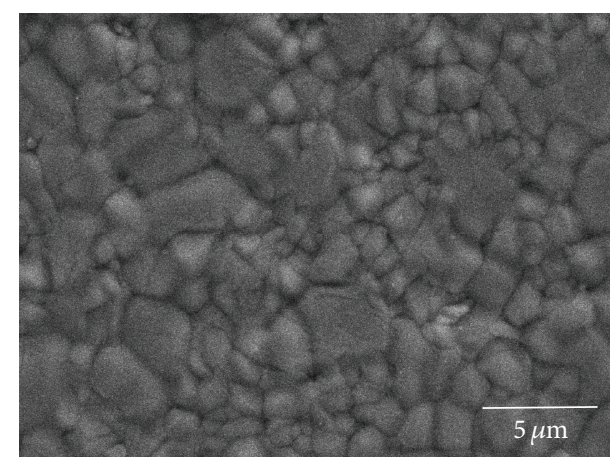

(d)

Figure 6: The SEM micrographs of the fabricated Zn-TCP ceramics: (a) Zn-TCP(0), (b) Zn-TCP(5), (c) Zn-TCP(10), and (d) Zn-TCP(15). 


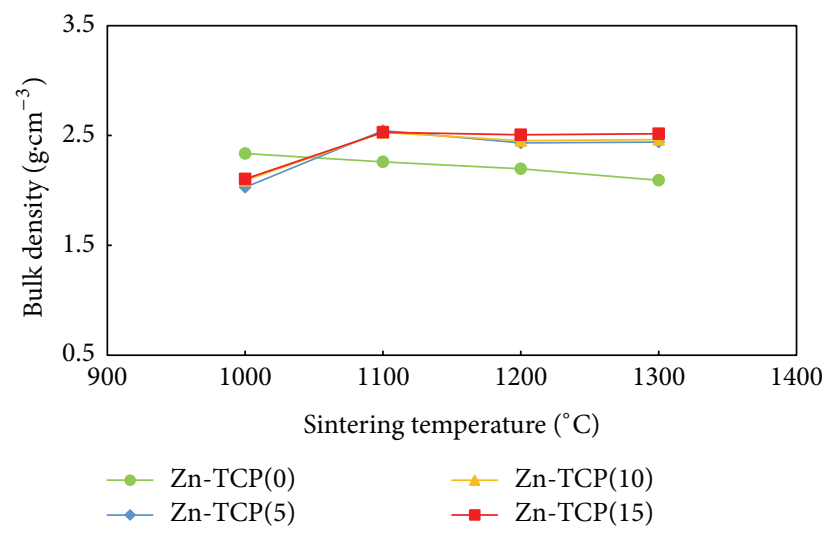

FIGURE 7: The relationship between the sintering temperature and the bulk density of the fabricated Zn-TCP ceramics.

TABLE 4: The value of the lattice constants in the fabricated $\mathrm{Zn}$-TCP ceramic samples.

\begin{tabular}{lcc}
\hline Sample & $a,(b)$-axis/nm & $c$-axis/nm \\
\hline Zn-TCP $(0)$ & $1.0429 \pm 0.0051$ & $3.7340 \pm 0.0184$ \\
Zn-TCP(5) & $1.0416 \pm 0.0016$ & $3.7380 \pm 0.0161$ \\
Zn-TCP(10) & $1.0426 \pm 0.0015$ & $3.7387 \pm 0.0250$ \\
Zn-TCP(15) & $1.0421 \pm 0.0036$ & $3.7371 \pm 0.0136$ \\
\hline
\end{tabular}

exists on the surface of ceramics. These data revealed that the structure of microspheres makes it difficult to obtain high bulk density of ceramics.

\section{Conclusions}

On the basis of the characterization of the synthesized $\mathrm{Zn}$ TCP powders and respective ceramics, it was possible to determine to what extent the incorporation of zinc ions in TCP structure influences the chemical properties of TCP. The results can be summarized as follows:

(i) The crystalline phases of the Zn-TCP powders consisted of $\alpha-, \beta$-TCP, and HAp phases. On the other hand, the Zn-TCP ceramics were almost composed of $\beta$-TCP phase.

(ii) The FT-IR spectra of the resulting Zn-TCP powders showed the characteristic absorption bands of TCP.

(iii) Contents of $\mathrm{Ca}, \mathrm{P}$, and $\mathrm{Zn}$ in $\mathrm{Zn}$-TCP powders and ceramics via ICP-AES showed the effectivity of the USSP technique for the synthesis of calcium phosphates with the desired stoichiometric composition.

(iv) The resulting Zn-TCP powders were composed of spherical shaped particles with a diameter smaller than $2 \mu \mathrm{m}$, whereas the median size grew with increasing zinc concentration. On the other hand, the microstructure of the Zn-TCP ceramics consisted of various sized grains. The grain size was affected by the incorporation of zinc ions into the TCP crystal structure. As a result, the grain size of $\mathrm{Zn}-\mathrm{TCP}(5,10$, $15)$ was smaller than that of $\mathrm{Zn}-\mathrm{TCP}(0)$. (v) The calculated lattice constants in the Zn-TCP ceramic samples indicated that the sintered compacts mainly contained $\beta$-TCP phase. However, the increasing zinc content only slightly affected the values of the $a$-axis, $b$-axis.

(vi) The relationship between the sintering temperatures and the bulk density showed that the bulk density of $\mathrm{Zn}-\mathrm{TCP}(5),(10)$, and (15) was the highest at $1100^{\circ} \mathrm{C}$ and then reached plateau. However, the bulk density of $\mathrm{Zn}-\mathrm{TCP}(0)$ was the highest at $1000^{\circ} \mathrm{C}$ and then decreased slightly.

\section{Abbreviations}

$\begin{array}{ll}\text { Zn-TCP: } & \text { Zinc-substituted tricalcium phosphate } \\ \text { HAp: } & \text { Hydroxyapatite }\end{array}$

USSP technique: Ultrasonic spray-pyrolysis technique.

\section{Competing Interests}

The authors declare that they have no competing interests.

\section{Authors' Contributions}

Hiroki Nishikawa and Michiyo Honda equally contributed to this work.

\section{References}

[1] L. L. Hench, "Bioceramics," Journal of the American Ceramic Society, vol. 81, no. 7, pp. 1705-1727, 1998.

[2] S. Ramakrisha, M. Ramalingam, T. S. S. Kumar, and W. O. Soboyejo, Biomaterials: A Nano Approach, CRC Press, Boca Raton, Fla, USA, 2010.

[3] F. Barrère, T. A. Mahmood, K. de Groot, and C. A. van Blitterswijk, "Advanced biomaterials for skeletal tissue regeneration: instructive and smart functions," Materials Science and Engineering: R: Reports, vol. 59, no. 1-6, pp. 38-71, 2008.

[4] T. Kanazawa, T. Umegaki, H. Monma, and K. Yamashita, "Materials chemistry of apatites," Gypsum \& Lime, vol. 210, pp. 261-273, 1987.

[5] G. L. Messing, S.-C. Zhang, and G. V. Jayanthi, "Ceramic powder synthesis by spray pyrolysis," Journal of the American Ceramic Society, vol. 76, no. 11, pp. 2707-2726, 1993.

[6] Y. L. Song, S. C. Tsai, C. Y. Chen et al., "Ultrasonic spray pyrolysis for synthesis of spherical zirconia particles," Journal of the American Ceramic Society, vol. 87, no. 10, pp. 1864-1871, 2004.

[7] G. An, H. J. Wang, B. H. Kim, Y. G. Jeong, and Y. H. Choa, "Fabrication and characterization of a hydroxyapatite nanopowder by ultrasonic spray pyrolysis with salt-assisted decomposition," Materials Science and Engineering: A, vol. 449451, pp. 821-824, 2007.

[8] S. Inoue and A. Ono, "Preparation of hydroxyapatite by spraypyrolysis technique," Journal of the Ceramic Society of Japan, vol. 95, pp. 759-763, 1987.

[9] V. Jokanovic and D. Uskokovic, "Calcium hydroxyapatite thin films on titanium substrates prepared by ultrasonic spray pyrolysis," Materials Transactions, vol. 46, no. 2, pp. 228-235, 2005. 
[10] M. Aizawa, K. Itatani, F. S. Howell, and A. Kishioka, "Effects of starting materials on properties of hydroxyapatite powders prepared by spray-pyrolysis technique," Journal of the Ceramic Society of Japan, vol. 104, no. 2, pp. 126-132, 1996.

[11] E. Dinu, C. D. Ghitulica, G. Voicu, and E. Andronescu, "Calcium phosphate powders obtained through the pyrosol method," Romanian Journal of Materials, vol. 41, pp. 248-254, 2011.

[12] K. Itatani, T. Nishioka, S. Seike, F. S. Howell, A. Kishioka, and M. Kinoshita, "Sinterability of $\beta$-calcium orthophosphate powder prepared by spray-pyrolysis," Journal of the American Ceramic Society, vol. 77, no. 3, pp. 801-805, 1994.

[13] M. Aizawa, Y. Miyamoto, K. Itatani, A. Kishioka, and M. Kinoshita, "Properties of calcium metaphosphate and calcium diphosphate powders prepared by spray-pyrolysis technique," Gypsum \& Lime, vol. 237, pp. 22-30, 1992.

[14] M. Aizawa, F. S. Howell, and K. Itatani, "Characterization of strontiumapatite powders prepared by ultrasonic spraypyrolysis technique," Journal of the Ceramic Society of Japan, vol. 107, no. 11, pp. 1007-1011, 1999.

[15] M. Honda, K. Kikushima, Y. Kawanobe, T. Konishi, M. Mizumoto, and M. Aizawa, "Enhanced early osteogenic differentiation by silicon-substituted hydroxyapatite ceramics fabricated via ultrasonic spray pyrolysis route," Journal of Materials Science: Materials in Medicine, vol. 23, no. 12, pp. 2923-2932, 2012.

[16] M. Honda, Y. Kawanobe, K. Ishii et al., "In vitro and in vivo antimicrobial properties of silver-containing hydroxyapatite prepared via ultrasonic spray pyrolysis route," Materials Science and Engineering C, vol. 33, no. 8, pp. 5008-5018, 2013.

[17] P. V. Giannoudis, H. Dinopoulos, and E. Tsiridis, "Bone substitutes: an update," Injury, vol. 36, pp. S20-S27, 2005.

[18] M. Yamaguchi, "Role of zinc in bone formation and bone resorption," Journal of Trace Elements in Experimental Medicine, vol. 11, no. 2-3, pp. 119-135, 1998.

[19] A. Ito, H. Kawamura, M. Otsuka et al., "Zinc-releasing calcium phosphate for stimulating bone formation," Materials Science and Engineering C, vol. 22, no. 1, pp. 21-25, 2002.

[20] X. Wang, X. Li, K. Onuma, Y. Sogo, T. Ohno, and A. Ito, "Znand $\mathrm{Mg}$ - containing tricalcium phosphates-based adjuvants for cancer immunotherapy," Scientific Reports, vol. 3, article 2203, 2013.

[21] L. Berzina-Cimdina and N. Borodajenko, Materials Science, Engineering and Technology, Edited by T. Theophile, InTech, 2012.

[22] O. Milošević, B. Jordović, and D. Uskoković, "Preparation of fine spherical $\mathrm{ZnO}$ powders by an ultrasonic spray pyrolysis method," Materials Letters, vol. 19, no. 3-4, pp. 165-170, 1994.

[23] K. Itatani, A. Kishioka, and M. Kinoshita, "Synthesis of starting powders for ceramics by spray-pyrolysis technique," Gypsum \& Lime, vol. 241, pp. 447-456, 1992.

[24] A. Ito, M. Otsuka, H. Kawamura et al., "Zinc-containing tricalcium phosphate and related materials for promoting bone formation," Current Applied Physics, vol. 5, no. 5, pp. 402-406, 2005.

[25] M. Yashima, A. Sakai, T. Kamiyama, and A. Hoshikawa, "Crystal structure analysis of $\beta$-tricalcium phosphate $\mathrm{Ca}_{3}\left(\mathrm{PO}_{4}\right)_{2}$ by neutron powder diffraction," Journal of Solid State Chemistry, vol. 175, no. 2, pp. 272-277, 2003.

[26] S. Gomes, J.-M. Nedelec, E. Jallot, D. Sheptyakov, and G. Renaudin, "Unexpected mechanism of $\mathrm{Zn}^{2+}$ insertion in calcium phosphate bioceramics," Chemistry of Materials, vol. 23, no. 12, pp. 3072-3085, 2011. 

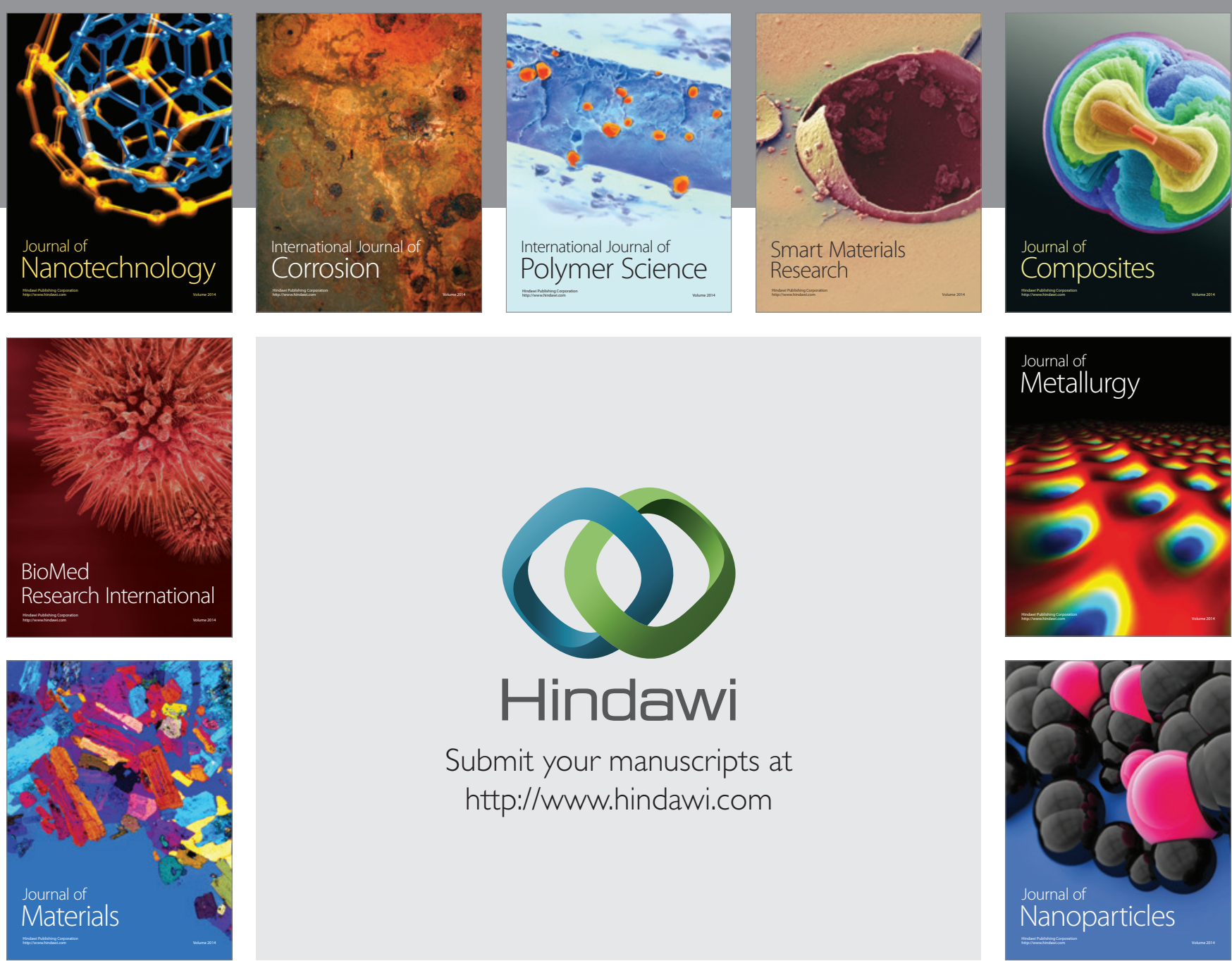

\section{Hindawi}

Submit your manuscripts at

http://www.hindawi.com

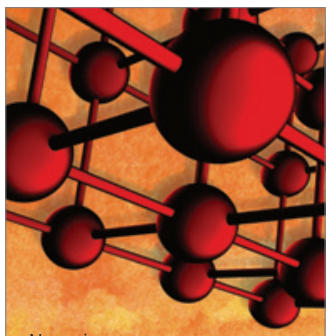

Materials Science and Engineering
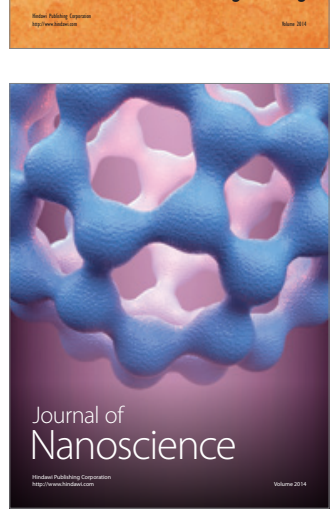
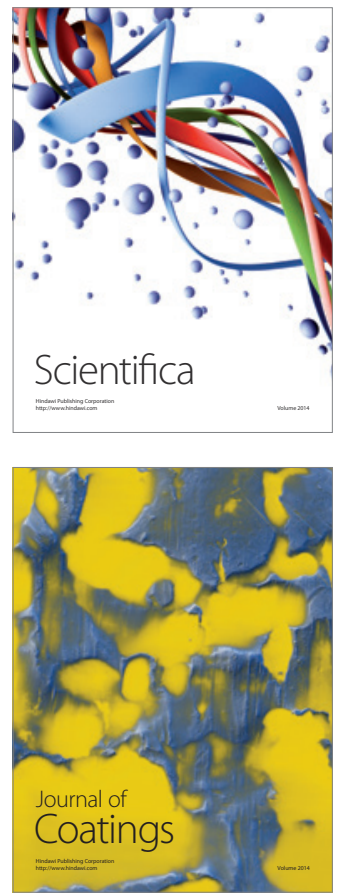
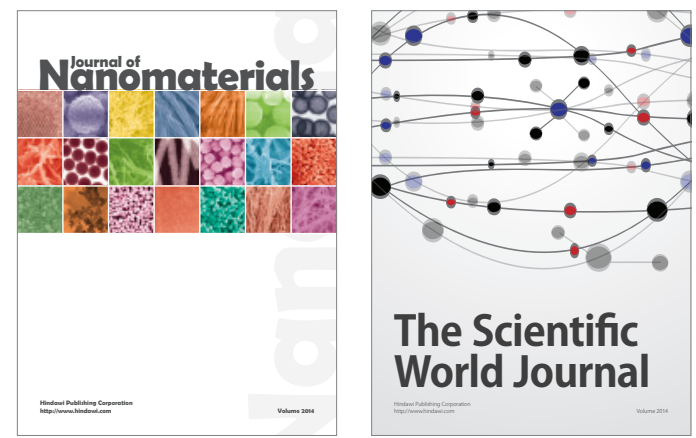

The Scientific World Journal
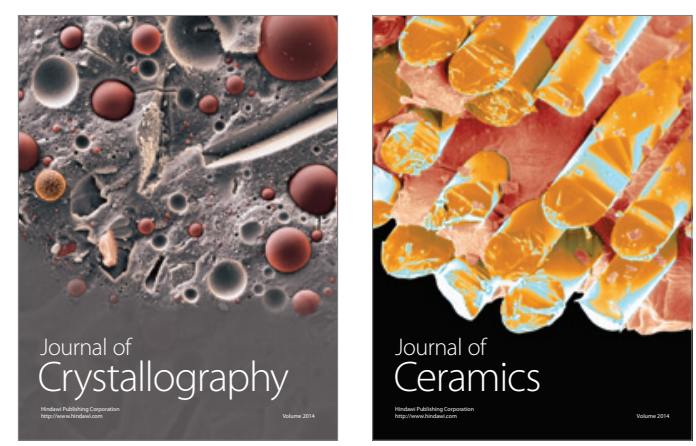
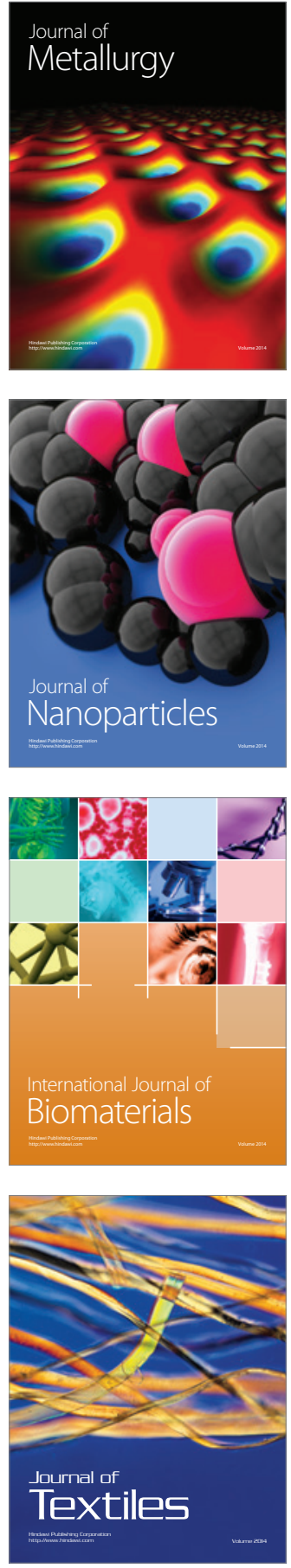